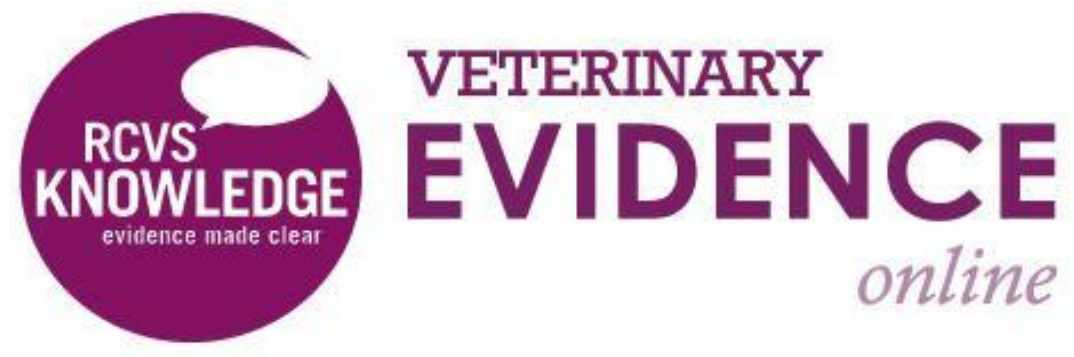

\title{
Tenoscopic Debridement or Surgical Repair for Longitudinal Tears of the Equine Deep Digital Flexor Tendon Within the Digital Flexor Tendon Sheath?
}

\section{A Knowledge Summary by}

Daniel Castillo MV MRCVS ${ }^{1 *}$

Neal Ashton BVet Med Cert EP Cert ES (Soft tissue) MRCVS ${ }^{2}$

\footnotetext{
${ }^{1}$ Pierson Stewart \& Partners, Brooksden Veterinary Hospital, High Street, Cranbrook, Kent, TN17 3DT

2 Oakham Veterinary Hospital, Ashwell Road, Oakham, Rutland, LE15 7QH

Corresponding Author (d.castillocastagneto@gmail.com)
}

ISSN: 2396-9776

Published: 07 June 2018

in: Vol 3, Issue 2

DOI: http://dx.doi.org/10.18849/ve.v3i2.164

Reviewed by: Sushmitha Durgam (BVSc, PhD, DACVS) and James Carmalt (MA, VetMB, MVetSc, FRCVS)

Next Review Date: 30 May 2019 
KNOWLEDGE SUMMARY

\section{PICO question}

In horses with longitudinal tears of the deep digital flexor tendon within the digital flexor tendon sheath, is surgical repair as effective as tenoscopic debridement alone for returning to previous level of performance?

\section{Clinical bottom line}

Current literature on the efficacy of surgical repair or tenoscopic debridement is limited. Criteria to define and evaluate performance outcomes is not uniform and confounded with multiple variables, merely representing low quality evidence that is difficult to draw meaningful conclusions from. However, the literature suggests tenoscopic debridement alone has been associated with improved outcomes. A more definitive conclusion cannot be made until higher quality evidence is made available on this topic.

\section{The Evidence}

The quality of the evidence comparing both treatment modalities is low and insufficient. Primarily, two authors provided data on performance outcomes for both treatment modalities, highlighting surgical repair as an inferior technique associated with reduced performance. Other authors solely assessed tenoscopic debridement alone, or may have included a very limited number $(n=2)$ of surgical repair cases that were unresponsive to previous tenoscopic surgery. Case selection may have introduced significant bias into these results as tenoscopic debridement alone is the preferred surgical technique, whilst surgical repair has been reserved for more extensive tears, or tears unresponsive to tenoscopic debridement. No randomised controlled trials are available to compare the efficacy of these treatment modalities.

\section{Summary of the evidence}

\begin{tabular}{|c|c|}
\hline \multicolumn{2}{|l|}{ Arensburg (2011) } \\
\hline Population: & $\begin{array}{l}\text { Horses with non-septic tenosynovitis of the Digital Flexor Tendon } \\
\text { Sheath }\end{array}$ \\
\hline Sample size: & $\mathrm{N}=130$ \\
\hline Intervention details: & $\begin{array}{l}\text { - All horses were examined tenoscopically under general } \\
\text { anaesthesia between } 1999 \text { and } 2009 \text {. } \\
\text { - Palmar annular ligament desmotomy was performed on } \\
\text { cases with evidence of chronicity or obvious thickening of } \\
\text { the ligament. Before } 2003 \text {, desmotomy was performed in all } \\
\text { cases. } \\
\text { - Torn tendon fibrils and granulomata were resected using a } \\
\text { motorised synovial resector and suction punch ronguers. } \\
\text { In some cases further debridement and smoothing of the } \\
\text { fibrillated edge was achieved using a coblation probe on a } \\
\text { low energy setting and in no contact mode. }\end{array}$ \\
\hline
\end{tabular}




\begin{tabular}{|c|c|}
\hline & $\begin{array}{l}\text { debridement was selected using an arthroscopic punch and } \\
\text { Ferris-Smith rongeurs. }\end{array}$ \\
\hline Study design: & Case series \\
\hline Outcome studied: & $\begin{array}{l}\text { Semi-objective } \\
\text { To evaluate the effect of different treatment modalities, post- } \\
\text { operative distension and duration of clinical signs prior to } \\
\text { presentation on the final functional outcome. }\end{array}$ \\
\hline $\begin{array}{l}\text { Main findings: } \\
\text { (relevant to PICO question): }\end{array}$ & $\begin{array}{l}\text { - Of } 130 \text { horses with chronic tenosynovitis of the digital flexor } \\
\text { tendon sheath (DFTS) that had tenoscopic surgery, } 101 \\
\text { horses were diagnosed with } 115 \text { longitudinal tears (LTs) } \\
\text { affecting a digital flexor tendon in } 104 \text { digital flexor tendon } \\
\text { sheaths. Palmar-plantar annular ligament (PAL) desmotomy } \\
\text { was performed in 71/104 DFTS (68\%). } \\
\text { - Follow-up on } 98 \text { horses revealed that } 37 \text { horses (38\%) } \\
\text { returned to a previous level of work or higher. } 27 \text { horses } \\
\text { (27\%) returned to a lower level of work and } 34 \text { horses (35\%) } \\
\text { remained lame. } \\
\text { - Coblation was associated with a lower level of performance } \\
\text { and cosmetic outcome (increased distension). } \\
\text { Manual debridement of LTs (no resector or coblation) was } \\
\text { associated with a better functional outcome. }\end{array}$ \\
\hline Limitations: & $\begin{array}{l}\text { - Retrospective case-series study. } \\
\text { - Multiple confounding variables affecting final functional } \\
\text { outcome. } \\
\text { - Poorly defined outcome assessment. }\end{array}$ \\
\hline
\end{tabular}

\begin{tabular}{|r|l|}
\hline Wilderjans (2003) & \multicolumn{2}{|c|}{ Population: } & $\begin{array}{l}\text { Warmblood horses with chronic tenosynovitis and annular ligament } \\
\text { constriction syndrome. }\end{array}$ \\
\hline Sample size: & $\mathrm{N}=25$ \\
\hline Intervention details: & $\begin{array}{l}\text { All horses were examined tenoscopically under general } \\
\text { anaesthesia between 1999-2000. }\end{array}$ \\
& $\begin{array}{l}\text { Desmotomy of the palmar annular ligament was performed } \\
\text { in all horses with a hook knife. }\end{array}$ \\
\hline Study design: & $\begin{array}{l}\text { In all cases, the torn fibres were resected using a motorised } \\
\text { synovial resector. }\end{array}$ \\
\hline Outcome studied: & $\begin{array}{l}\text { Semi-objective } \\
\text { To evaluate the incidence of longitudinal tears as the underlying } \\
\text { cause of chronic tenosynovitis and annular ligament constriction } \\
\text { syndrome in Warmblood horses. To evaluate the final outcome after } \\
\text { tenoscopic debridement and palmar annular ligament desmotomy. } \\
\text { Postoperative distension, ultrasonographic findings and level of } \\
\text { performance were assessed. }\end{array}$ \\
\hline
\end{tabular}




\begin{tabular}{|c|c|}
\hline $\begin{array}{l}\text { Main findings: } \\
\text { (relevant to PICO question): }\end{array}$ & $\begin{array}{l}\text { - Of } 25 \text { horses, } 17 \text { were diagnosed with a longitudinal tear. } \\
\text { - After } 12-24 \text { months, } 10 \text { horses ( } 59 \%) \text { were sound and } \\
\text { resumed their previous level of work. Four horses ( } 24 \%) \\
\text { returned to their previous level of work but needed } \\
\text { intrasynovial treatment of the DFTS and reduced } \\
\text { competition frequency to remain sound. Three horses (18\%) } \\
\text { remained lame. }\end{array}$ \\
\hline Limitations: & $\begin{array}{l}\text { - Retrospective case-series study. } \\
\text { - } \quad \text { Surgical repair was not considered by the author because } \\
\text { the tear edges were always in close apposition. } \\
\text { The author states suture repair requires a large open } \\
\text { approach which are prone to a greater risk of post-operative } \\
\text { complications, such as partial wound dehiscence and } \\
\text { leakage from the tendon sheath, although no references are } \\
\text { provided to support this. }\end{array}$ \\
\hline
\end{tabular}

\begin{tabular}{|c|c|}
\hline 006) & \\
\hline Population: & Horses with non-infected tenosynovitis of the DFTS. \\
\hline Sample size: & $\mathrm{N}=108$ \\
\hline Intervention details: & $\begin{array}{l}\text { - All horses had diagnostic tenoscopy under general } \\
\text { anaesthesia between } 1999 \text { and } 2005 . \\
\text { - Desmotomy of the PAL was performed from } 1999 \text { to } 2003 \\
\text { using a hook meniscectomy knife. From 2003, PAL } \\
\text { desmotomies were performed only if there was an obvious } \\
\text { thickening of the PAL. } \\
\text { - Longitudinal tears were debrided with a motorised synovial } \\
\text { resector, followed by further microdebridement in some } \\
\text { cases using coblation wands. Arthroscopic Ferris-Smith } \\
\text { rongeurs were used to remove the larger masses of torn } \\
\text { tendon fibres, fibrin, and to remove synovial adhesions. } \\
\text { - Fibrillation of the palmar/plantar surface of the superficial } \\
\text { digital flexor tendon (SDFT was smoothened with coblation. }\end{array}$ \\
\hline Study design: & Case Series \\
\hline Outcome studied: & $\begin{array}{l}\text { Semi-objective } \\
\text { To evaluate the final functional outcome and performance of horses } \\
\text { suffering from longitudinal tears in one or more flexor tendons. To } \\
\text { evaluate the relation between final outcome and treatment with } \\
\text { synovial resector, coblation, PAL resection, length of the tear, } \\
\text { presence of post-operative distension and duration of clinical signs. }\end{array}$ \\
\hline $\begin{array}{l}\text { Main findings: } \\
\text { (relevant to PICO question): }\end{array}$ & $\begin{array}{l}\text { - } 71 \text { horses were diagnosed with LTs in } 73 \text { DFTSs examined } \\
\text { tenoscopically. } \\
\text { - Follow-up on } 69 \text { horses (71 DFTS) revealed that } 26 \text { horses } \\
\text { (38\%) returned to their previous level of work or higher. } 26\end{array}$ \\
\hline
\end{tabular}




\begin{tabular}{|c|c|}
\hline & $\begin{array}{l}\text { horses (38\%) returned to a lower level of work, and } 17 \\
\text { horses }(25 \%) \text { remained lame. } \\
\text { - Surgical repair was performed on } 2 \text { cases with LTs of the } \\
\text { lateral edge of the DDFT unresponsive to tenoscopic } \\
\text { debridement. One horse returned to previous level of work } \\
\text { and the other one to a lower level of work. } \\
\text { Desmotomy of the PAL and the use of coblation do not seem } \\
\text { to affect the final outcome. }\end{array}$ \\
\hline Limitations: & $\begin{array}{l}\text { - Retrospective case-series study. } \\
\text { - } \quad \text { Insuffed statistical analysis. } \\
\text { - Multiple confounding variables affecting final functional } \\
\text { outcome. }\end{array}$ \\
\hline
\end{tabular}

\begin{tabular}{|c|c|}
\hline & \\
\hline Population: & Horses with non-infected tenosynovitis of the digital FTS. \\
\hline Sample size: & $N=76$ \\
\hline Intervention details: & $\begin{array}{l}\text { - All horses were evaluated tenoscopically under general } \\
\text { anaesthesia between } 1^{\text {st }} \text { January } 1996 \text { and } 31^{\text {st }} \text { December } \\
2003 . \\
65 \text { horses underwent treatment with tenoscopic techniques } \\
\text { only. } \\
\text { - Large masses of torn tendon tissue and granulomata were } \\
\text { dissected free with arthroscopic scissors or meniscectomy } \\
\text { knives before removal with Ferris-Smith arthroscopic } \\
\text { rongeurs. } \\
\text { - Tendinous defects were also debrided with a motorised } \\
\text { synovial resector in an oscillating mode with suction applied. } \\
\text { PAL desmotomy was performed in } 2 \text { horses using an } \\
\text { endoscopically assisted 'freehand' technique using a curved } \\
\text { meniscectomy knife. } \\
\text { Partial tears of the manica flexoria (MF) were debrided (n=5) } \\
\text { and the MF was removed in its entirety when one margin } \\
\text { was disrupted completely (n=18). The opposite, intact } \\
\text { margin was divided from the SDFT using arthroscopic } \\
\text { scissors and/or meniscectomy knives. } \\
11 \text { horses underwent open surgery for repair or removal of } \\
\text { lesions identified at tenoscopy. Repair of torn DDFT, SDFT } \\
\text { and MF was performed with simple continuous sutures of } 2 \\
\text { or } 3 \text { metric polyglactin } 910 \text { (Vicryl). Incision closure involved } \\
\text { repair of sectioned MF, PALs and sheath walls with simple } \\
\text { continuous sutures of } 3 \text { metric polyglactin } 910 \text {. This was } \\
\text { followed by a subcuticular layer of the same material and by } \\
\text { stainless steel staples in the skin. } \\
\text { open surgical approach. }\end{array}$ \\
\hline
\end{tabular}




\begin{tabular}{|c|c|}
\hline & $\begin{array}{l}\text { - Tenoscopy skin portals were closed with simple interrupted } \\
\text { sutures of monofilament polyamide. }\end{array}$ \\
\hline Study design: & Case Series \\
\hline Outcome studied: & $\begin{array}{l}\text { Semi-objective } \\
\text { To evaluate the clinical features, diagnoses, treatment and outcomes } \\
\text { of a series of horses with non-infected tenosynovitis of the DFTS. To } \\
\text { identify significant associations between the } 3 \text { dependent variables } \\
\text { (lameness; performance; distension) and the clinical variables. }\end{array}$ \\
\hline $\begin{array}{l}\text { Main findings: } \\
\text { (relevant to PICO question): }\end{array}$ & $\begin{array}{l}\text { - } 46 \text { longitudinal tears of the DDFT were identified in } 44 \\
\text { horses. Tears of the DDFT occurred in combination with } \\
\text { tears of the MF ( } n=5 \text { ) and SDFT ( } n=1) \text {. Two further cases had } \\
\text { thickening of the PAL. Adhesions were present between the } \\
\text { torn surface of the DDFT and the DFTS wall in } 4 \text { cases. } \\
\text { - Follow-up information ( }>6 \text { months) post-surgery was } \\
\text { available for } 61 \text { horses. } \\
\text { - Follow-up on } 33 \text { horses with longitudinal tears of the DDFT } \\
\text { revealed that } 14 \text { horses ( } 42 \% \text { ) returned to their previous } \\
\text { level of performance. } \\
\text { LTs of the DDFT and open surgical repair of the DDFT lesions } \\
\text { were associated with reduced post-operative performance. }\end{array}$ \\
\hline Limitations: & $\begin{array}{l}\text { - Retrospective case series study. } \\
\text { - Selection bias represented in some cases with severe lesions } \\
\text { of the DDFT having surgical repair. } \\
\text { - Multiple factors confounding treatment outcomes. }\end{array}$ \\
\hline
\end{tabular}

Wright (1999)

\begin{tabular}{|c|c|}
\hline Population: & $\begin{array}{l}\text { Horses with tenosynovitis associated with longitudinal tears of the } \\
\text { DDFT. }\end{array}$ \\
\hline Sample size: & $N=20$ \\
\hline Intervention details: & $\begin{array}{l}\text { - All horses were evaluated surgically under general } \\
\text { anaesthesia. } \\
\text { - } \quad \text { Diagnosis was established by tenoscopy in } 9 \text { horses. } \\
\text { - } \text { surgical approach to the DFTS. } \\
\text { - In } 7 \text { horses torn tendon fibrils were removed tenoscopically } \\
\text { with a motorised synovial resector. } \\
\text { - In } 13 \text { horses, } 14 \text { DFTSs were explored surgically. } \\
\text { - Identification of the proximal extent of the deep digital } \\
\text { flexor tendon lesions necessitated section of the enclosing } \\
\text { manica flexoria in } 9 \text { limbs. } \\
\text { Torn tendon fibrils were removed by sharp dissection. } \\
\text { Where present, granulomata and adhesions were also } \\
\text { excised. } \\
11 \text { horses had surgical repair of DDFT lesions in } 12 \text { limbs. In } \\
10 \text { limbs the repair was performed with simple continuous }\end{array}$ \\
\hline
\end{tabular}




\begin{tabular}{|c|c|}
\hline & $\begin{array}{l}\text { sutures of } 2 \text { or } 3 \text { metric polyglactin } 910 \text { (Vicryl) and in } 2 \\
\text { horses simple interrupted sutures of } 1.5 \text { metric } \\
\text { polydioxanone (PDS). } \\
\text { - Torn ( } n=2 \text { ) or sectioned manica flexoria were repaired by } \\
\text { simple continuous sutures of } 2 \text { metric polyglactin } 910 \text {. } \\
\text { - The tendon sheaths and palmar/plantar annular ligaments } \\
\text { were closed with simple continuous sutures of } 3 \text { metric } \\
\text { polyglactin } 910 \text {. This was followed by a subcuticular layer of } \\
\text { similar material and stainless steel staples in the skin. } \\
\text { - Tenoscopic portals were closed with simple interrupted } \\
\text { sutures of monofilament polyamide. }\end{array}$ \\
\hline Study design: & Case Series \\
\hline Outcome studied: & $\begin{array}{l}\text { Semi-objective } \\
\text { To evaluate clinical characteristics of horses with tenosynovitis } \\
\text { associated with longitudinal tears and ability to return to work. }\end{array}$ \\
\hline $\begin{array}{l}\text { Main findings: } \\
\text { (relevant to PICO question): }\end{array}$ & $\begin{array}{l}\text { - } 19 \text { tears of the DDFT and } 2 \text { tears the manica flexoria were } \\
\text { identified in } 20 \text { horses. } \\
\text { - Follow-up information was obtained by telephone from } \\
\text { owners and, or, trainers. } \\
\text { - Five horses were re-examined post-operatively; } 3 \text { at } 4 \\
\text { months, } 1 \text { at } 7 \text { months and } 1 \text { at } 10 \text { months after surgery. } 3 \text { of } \\
\text { these were sound and } 2 \text { were lame. } \\
\text { - } 7 \text { horses with DDFT lesions treated tenoscopically, } 4 \text { were } \\
\text { sound and in work, } 3 \text { were in controlled exercise } \\
\text { programmes. } \\
\text { Of } 11 \text { horses with surgical repair of DDFT lesions, } 5 \text { were } \\
\text { sound and in work, } 1 \text { was sound and in controlled exercise, } 5 \\
\text { were lame. } \\
\text { The prognosis for horses with tears of the DDFT which are } \\
\text { treated by tenoscopic removal of torn tendon fibrils is better } \\
\text { than that for animals treated by subsequent repair of the } \\
\text { defect. The repaired tears in the DDFT were, on the whole, } \\
\text { considered to be more extensive. It is not yet possible to } \\
\text { determine whether the apparently inferior prognosis results } \\
\text { from the extent of the lesion, the surgical technique used or } \\
\text { the repair process. }\end{array}$ \\
\hline Limitations: & $\begin{array}{l}\text { - Retrospective case-series study. } \\
\text { - Selection bias for surgical repair of DDFT lesions. } \\
\text { - } \text { opjective outcome assessment used to determine post- } \\
\text { - Multiple factors confounding treatment outcomes. }\end{array}$ \\
\hline
\end{tabular}

Appraisal, application and reflection 
The five relevant identified studies discussing the outcome of tenoscopic debridement alone, versus surgical repair of LTs, are retrospective case series. This represents evidence of low quality and reliability.

Cases within and between studies have been managed using different treatment modalities. Diagnostic tenoscopy is often performed to assess the severity and extent of the lesions affecting the border of the DDFT. Criteria for treatment selection is poorly defined and primarily based on the surgeon's experience and preference. Torn tendon fibrils and granulomata are resected using a motorised synovial resector, or by manual debridement with an arthroscopic punch, Ferris-Smith rongeurs, and in some cases arthroscopic scissors or meniscectomy knives. Further debridement was pursued in several cases with the use of coblation.

Surgical repair has been reported using an open approach subsequent to initial tenoscopic debridement to gain complete access to the longitudinal tear (Smith et al., 2006; Wright et al., 1999). In some cases, this necessitated sectioning of the manica flexoria to gain access to the proximal extent of the tear. Tear repairs were performed with a simple continuous suture of 2 or 3 metric polyglactin 910 or polydioxanone. Less frequently, repairs have been performed with simple interrupted sutures of 1.5 metric polydioxanone. Incision closure involves repair of sectioned manica flexoria, palmar or plantar annular ligaments and sheath walls with simple continuous sutures of 2 or 3 metric polyglactin 910, followed by a subcuticular layer of the same material and stainless steel staples in the skin.

Current evidence from published literature, suggests that tenoscopic debridement, without repair of longitudinal tears, is the preferred treatment method. Open surgical repair of DDFT lesions have been associated with reduced post-operative performance. Although tenoscopic debridement has been associated with improved functional outcomes, animals treated by surgical repair were considered to have more extensive DDFT tears, or tears unresponsive to tenoscopic debridement. Case selection inherently added significant bias to the results, which is identified in more than one study. Since the repaired longitudinal tears were, on the whole, considered to be more extensive, it is not yet possible to determine whether the inferior prognosis results from the extent of the lesion, the surgical technique used or the repair process (Wright et al., 1999). Some cases with severe lesions were repaired based on the observation that intrinsic tendon repair mechanisms, derived primarily from the epitenon, promoted tendon healing following surgical repair in experimental conditions (Gelberman et al., 1983, cited in Smith et al., 2006). Another study also reported that surgical repair was only performed on 2 cases with LTs of the lateral border of the DDFT unresponsive to tenoscopic debridement (Wilderjans et al., 2006).

Although outcomes following surgical repair were less successful than tenoscopic debridement, there are likely many confounding factors in these case series which need consideration. Some of these include prior medical or surgical treatment, duration of clinical signs prior to presentation, severity and extent of the tear, concomitant pathology, treatment modality and technique, rehabilitation, intrinsic mechanisms of repair, and outcome assessment.

Until randomised controlled trials directly comparing tenoscopic debridement and surgical repair are made available, drawing meaningful conclusions from the current literature is limited.

\section{Methodology Section}

\section{Search Strategy}

Databases searched and dates CAB Abstracts on the OVID platform; 1973 to 05/2017

covered: Pubmed via the NCBI website; 1910 to 05/2017

Search terms: CAB Abstracts:

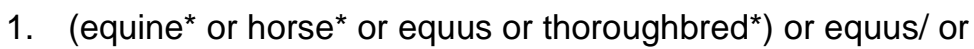
horses/ or thoroughbred/

2. ((tear* or laceration* or 'longitudinal tear' or 'marginal tear" or LT or LTs or defect) and ('deep digital flexor tendon' or

'DDFT' or 'flexor tendon' or 'tendon' or 'digital flexor tendon sheath' or DFTS or 'tendon sheath' or sheath*))

3. 1 and 2

4. ('suture repair' or 'surgical repair' or sutur* or repair* or 


\begin{tabular}{|c|c|}
\hline & 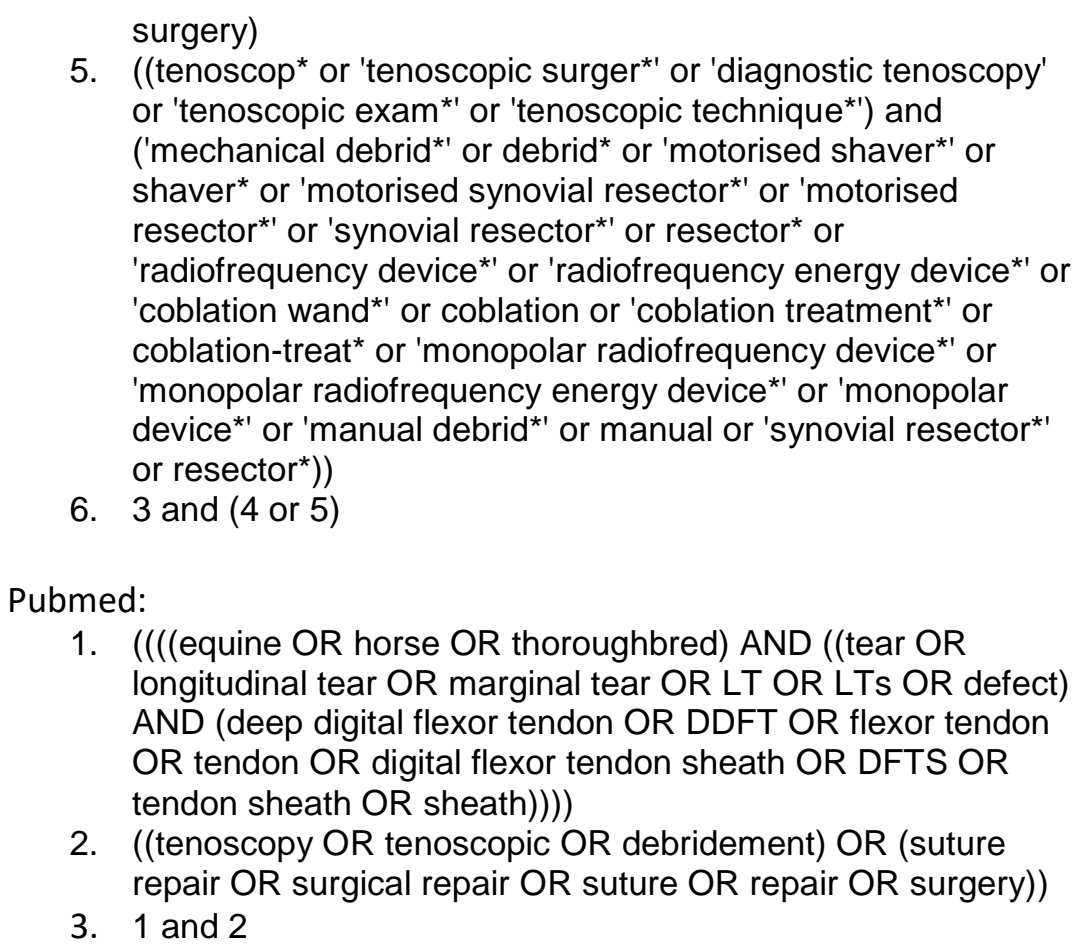 \\
\hline Dates searches performed: & $30 / 5 / 2017$ \\
\hline
\end{tabular}

Exclusion / Inclusion Criteria

Exclusion: Non-English language publications, studies performed in other species, articles not relevant to the PICO.

Inclusion: Studies available in English relevant to the PICO

\begin{tabular}{|l|c|c|c|c|c|c|}
\hline \multicolumn{2}{|l|}{ Search Outcome } \\
\hline Database & $\begin{array}{r}\text { Number } \\
\text { of } \\
\text { results }\end{array}$ & $\begin{array}{r}\text { Excluded - } \\
\text { Studies in } \\
\text { other } \\
\text { species }\end{array}$ & $\begin{array}{r}\text { Excluded - Non- } \\
\text { English articles }\end{array}$ & $\begin{array}{c}\text { Excluded - Not } \\
\text { relevant to PICO }\end{array}$ & $\begin{array}{c}\text { Excluded - } \\
\text { Duplicates }\end{array}$ & $\begin{array}{c}\text { Total } \\
\text { relevant } \\
\text { papers }\end{array}$ \\
\hline $\begin{array}{l}\text { CAB } \\
\text { Abstracts }\end{array}$ & 72 & 0 & 13 & 54 & 0 & 5 \\
\hline Pubmed & 46 & 3 & 1 & 38 & 4 & 0 \\
\hline Total relevant papers & & & & & 5 \\
\hline
\end{tabular}




\section{CONFLICT OF INTEREST}

The authors declare no conflicts of interest.

\section{REFERENCES}

1. Arensburg, L., Wilderjans, H., Simon, O., et al., (2011) Nonseptic tenosynovitis of the digital flexor tendon sheath caused by longitudinal tears in the digital flexor tendons: A retrospective study of 135 tenoscopic procedures. Equine vet. J. 43 (6) 660-668. DOI: http://dx.doi.org/10.1111/j.20423306.2010.00341.x

2. Smith, M.R.W., Wright, I.M. (2006) Noninfected tenosynovitis of the digital flexor tendon sheath: a retrospective analysis of 76 cases. Equine vet. J. 38, 134-141.

DOI: http://dx.doi.org/10.2746/042516406776563350

3. Wilderjans, H., Boussauw, B., Madder, K., et al., (2003) Tenosynovitis of the digital flexor tendon sheath and annular ligament constriction syndrome caused by longitudinal tears in the deep digital flexor tendon: a clinical and surgical report of 17 cases in Warmblood horses. Equine vet. J. 35, 270275. DOI: http://dx.doi.org/10.2746/042516403776148183

4. Wilderjans, H., Boussauw, B. (2006) Deep digital flexor tendon lesions in the fetlock region: a retrospective study of 108 tenoscopies of digital flexor tendon sheaths suspected of deep digital flexor tendon laceration. Management of lameness causes and sport horses: muscle, tendon, joint and bone disorders. Conference on Equine Sports Medicine and Science. Cambridge, UK. 21-23 July 2006: 15-25.

5. Wright, I.M., McMahon, P.J. (1999) Tenosynovitis associated with longitudinal tears of the digital flexor tendons in horses: a report of 20 cases. Equine vet. J. 31, 12-18. DOI: http://dx.doi.org/10.1111/j.20423306.1999.tb03785.x 


\section{Cantand
EVIDENCE \\ oflue}

\section{Intellectual Property Rights}

Authors of Knowledge Summaries submitted to RCVS Knowledge for publication will retain copyright in their work, and will be required to grant RCVS Knowledge a non-exclusive license of the rights of copyright in the materials including but not limited to the right to publish, re-

publish, transmit, sell, distribute and otherwise use the materials in all languages and all media throughout the world, and to license or permit others to do so.

\section{Disclaimer}

Knowledge Summaries are a peer-reviewed article type which aims to answer a clinical question based on the best available current evidence. It does not override the responsibility

of the practitioner. Informed decisions should be made by considering such factors as individual clinical expertise and judgement along with patient's circumstances and owners' values. Knowledge Summaries are a resource to help inform and any opinions expressed within the Knowledge Summaries are the author's own and do not necessarily reflect the view of the RCVS Knowledge. Authors are responsible for the accuracy of the content. While the

Editor and Publisher believe that all content herein are in accord with current recommendations and practice at the time of publication, they accept no legal responsibility

for any errors or omissions, and make no warranty, express or implied, with respect to material contained within.

For further information please refer to our Terms of Use.

RCVS Knowledge is the independent charity associated with the Royal College of Veterinary Surgeons (RCVS). Our ambition is to become a global intermediary for evidence based veterinary knowledge by providing access to information that is of immediate value to practicing veterinary professionals and directly contributes to evidence based clinical decision-making.

RCVS Knowledge is a registered Charity No. 230886. Registered as a Company limited by guarantee in England and Wales No. 598443.

Registered Office:

Belgravia House

62-64 Horseferry Road

London SW1P 2AF 